\title{
Population Differences in Gene Frequency of the Japanese Scallop Patinopecten yessoensis on the Okhotsk Sea Coast of Hokkaido
}

\author{
Akihiro KIJIMA, ${ }^{* 1}$ Katsuyoshi MoRI, ${ }^{* 2}$ and Yoshihisa FuJIO ${ }^{* 2}$ \\ (Accepted June 6, 1983)
}

\begin{abstract}
Genetic variability in native and sown populations, including 10 collections, of the Japanese scallop Patinopecten yessoensis on the Okhotsk Sea coast of Hokkaido in Japan was surveyed by starch gel electrophoresis for 19 genetic loci. As a whole, the proportion of polymorphic loci averaged $0.405 \pm 0.008$ and the average heterozygosity $0.158 \pm 0.002$, and these values were remarkably higher than those estimated for fish.

Any two of the 10 collections showed clear differences in gene frequencies at more than one locus except for a few combinations, indicating that they have a breeding structure independent of each other. The mean genetic distance was larger among native populations than among sown populations. The genetic distance was $0.0035 \pm 0.0003$ on the average for all populations, the value being smaller than 0.01 that is considered as the level of local race. However, the mean genetic distance between native Notoro Lake population and the other native populations was $0.0077 \pm 0.0008$, the value being the largest. These results suggest that the scallop population has a structure capable of being split into a number of local subpopulations.
\end{abstract}

The Japanese scallop Patinopecten yessoensis is distributed along the coastal waters of Hokkaido and north-east Honshu in Japan. Because of its habitat requirements and distribution, this species is one of desirable subjects for studying genetic-environment interaction in the stocks of different geographical origins.

Several studies on the geographical distribution of enzyme variability in marine molluscs have revealed that the genetic differences are present among localities. For the bay mussel Mytilus

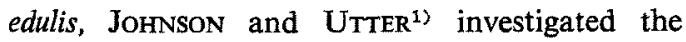
distribution of aspartate aminotransferase (AAT) and peptidase alleles in the collections from the west and east coasts of North America and found a cline for AAT alleles on the Pacific coast and a marked difference of peptidase allele frequency among collections from southern California, the North Pacific Ocean and New Jersey in U.S.A. For the Pacific oyster Crassostrea gigas, Funı') analyzed the 18 wild populations by using as markers the genes at five polymorphic loci controlling isocitrate dehydrogenase, phosphoglucomutase, glucosephosphate isomerase, aspartate aminotransferase and leucine aminopeptidase, and revealed that any two of the 18 wild populations showed clear differences in gene frequencies, suggesting that the population structure of the wild Pacific oyster as a whole has a tendency to split into a number of local subpopulations. For the Japanese scallop $P$. yessoensis, Fumno and MATSUYA $^{3)}$ found a marked difference in distribution of $\alpha$-glycerophosphate dehydrogenase alleles between Saroma Lake of Hokkaido and Noda Bay of Iwate Prefecture in Japan. YAMANAKA and Funo ${ }^{4}$ examined the distribution of alleles at the 22 loci controlling 13 enzymes and 3 muscle proteins in six collections from Hokkaido and Aomori, Iwate, Miyagi and Fukushima Prefectures in Japan, and indicated that the mean genetic distance calculated by NeI's formula was 0.036 among localities and 0.068 between Hokkaido and the other localities.

This paper presents the results of genetic variation in the 10 localities of native and sown scallops. The data include (1) genetic differences among localities on the Okhotsk Sea coast of Hokkaido, (2) estimate of genetic distance among localities, and (3) relationship between native and sown populations.

\section{Materials and Methods}

Native and sown scallops were collected from

*1 Present address: Department of Cultural Fisheries, Faculty of Agriculture, Kochi University, Nankoku, Kochi Pref. 783, Japan (木島明博：東北大学農学部; 現所属：高知大学農学部).

*2 Department of Fishery Science, Faculty of Agriculture, Tohoku University, Sendai 980, Japan (森 膦 義・藤尾芳久：東北大学農学部)。 


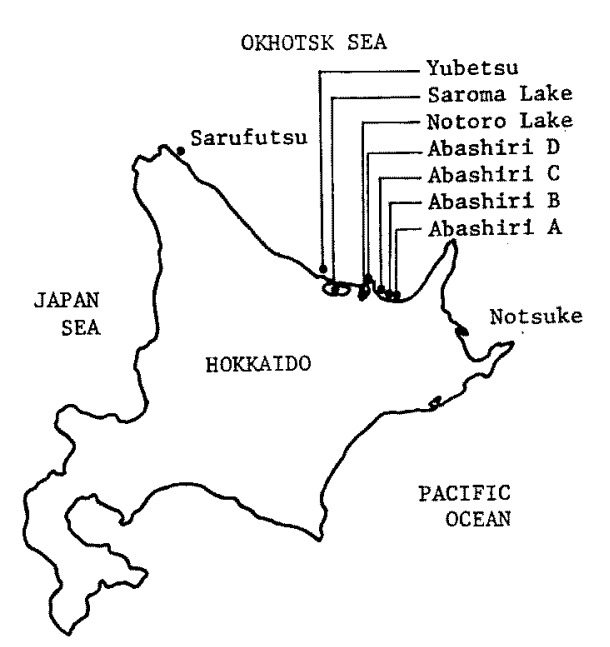

Fig. 1. Localities where samples of scallop were collected.

April to October in 1982 from the 10 localities along the Okhotsk Sea coast of Hokkaido (Fig. 1). The native scallops were collected from Notsuke, Abashiri A, Abashiri B, Notoro Lake and Sarufutsu. Although the collection from Saroma Lake was cultured by the hanging method, it was tentatively included in native scallops, since the seeds were produced there. The sown scallops were collected from Abashiri B, Abashiri C, Abashiri D and Yubetsu. The scallops under culture in Saroma Lake were observed to suffer from mass mortalities, exhibiting a high degree of deformed shells. The ages of these experimental materials are represented in Table 2.

The tissue extraction and starch gel electrophoresis were carried out by the method described previously ${ }^{5}$. Staining recipes for all enzymes except AAT followed those of SHAW and PRASAD ${ }^{\text {B) }}$. The staining procedure for AAT used here was the same as described by Sugrta and Funo ${ }^{7}$. The enzymes examined, their abbreviations, tissue source and abbreviation of loci scored are presented in Table 1. Loci were numbered consecutively from the most anodal to the most cathodal and alleles were designated alphabetically. For example, $I d h-2^{A}$ would refer to an allele of the second $I d h$ locus whose protein product migrates to the most anodal.

\section{Results}

\section{Genetic Variability within Populations}

A total of 19 genetic loci controlling the 11 kinds of enzymatic and nonenzymatic proteins were examined by starch gel electrophresis. The

Table 1. Enzyme surveyed, tissue sources, assigned loci and genetic variations in the scallop

\begin{tabular}{|c|c|c|c|c|c|}
\hline Enzyme & Abbreviation & Tissue source & Locus & $\begin{array}{c}\text { Genetic } \\
\text { variation }\end{array}$ & $\begin{array}{l}\text { Number } \\
\text { of allele }\end{array}$ \\
\hline \multirow[t]{2}{*}{ Acid phosphatase } & \multirow[t]{2}{*}{ ACP } & \multirow[t]{2}{*}{ Digestive diverticula } & $A c p-1$ & $\mathbf{M}$ & 1 \\
\hline & & & $A c p-2$ & M & 1 \\
\hline Phosphoglucomutase & PGM & Adductor muscle & $P g m$ & $\mathbf{P}$ & 6 \\
\hline$\alpha$-Glycerophosphate dehydrogenase & $\alpha \mathrm{GPD}$ & Adductor muscle & $\alpha G p d$ & $\mathbf{P}$ & 4 \\
\hline \multirow{2}{*}{ Isocitrate dehydrogenase } & \multirow[t]{2}{*}{ IDH } & Adductor muscle & $I d h-1$ & $\mathrm{P}^{*}$ & 4 \\
\hline & & Digestive diverticula & $I d h-2$ & $\mathbf{P}$ & 3 \\
\hline \multirow{2}{*}{ Malate dehydrogenase } & \multirow[t]{2}{*}{$\mathrm{MDH}$} & \multirow[t]{2}{*}{ Adductor muscle } & $M d h-1$ & $\mathbf{P}^{*}$ & 3 \\
\hline & & & $M d h-2$ & $\mathbf{P}^{*}$ & 2 \\
\hline 6-Phosphogluconate dehydrogenase & 6PGD & Adductor muscle & $6 P g d$ & $\mathbf{P}^{*}$ & 4 \\
\hline Glucosephosphate isomerase & GPI & Adductor muscle & $G p i$ & $\mathbf{P}$ & 3 \\
\hline \multirow[t]{2}{*}{ Aspartate aminotransferase } & \multirow[t]{2}{*}{ AAT } & \multirow[t]{2}{*}{ Adductor muscle } & Aat-1 & $\mathbf{P}$ & 4 \\
\hline & & & Aat -2 & $\mathbf{P}$ & 2 \\
\hline \multirow[t]{3}{*}{ Superoxide dismutase } & \multirow[t]{3}{*}{ SOD } & \multirow[t]{3}{*}{ Adductor muscle } & Sod-1 & $\mathrm{P}^{*}$ & 2 \\
\hline & & & Sod-2 & $\mathbf{M}$ & 1 \\
\hline & & & Sod-3 & $\mathbf{P}$ & 4 \\
\hline \multirow[t]{2}{*}{ Malic enzyme } & \multirow[t]{2}{*}{ ME } & \multirow[t]{2}{*}{ Adductor muscle } & $M e-1$ & - & - \\
\hline & & & $M e-2$ & $\mathbf{P}$ & 3 \\
\hline \multirow[t]{5}{*}{ Nonenzymatic protein } & \multirow[t]{5}{*}{ PT } & \multirow[t]{5}{*}{ Adductor muscle } & $P t-1$ & $\mathbf{M}$ & 1 \\
\hline & & & $P t-2$ & $\mathbf{M}$ & 1 \\
\hline & & & $P t-3$ & $\mathbf{P}$ & 2 \\
\hline & & & $P t-4$ & - & - \\
\hline & & & $P t-5$ & - & - \\
\hline
\end{tabular}



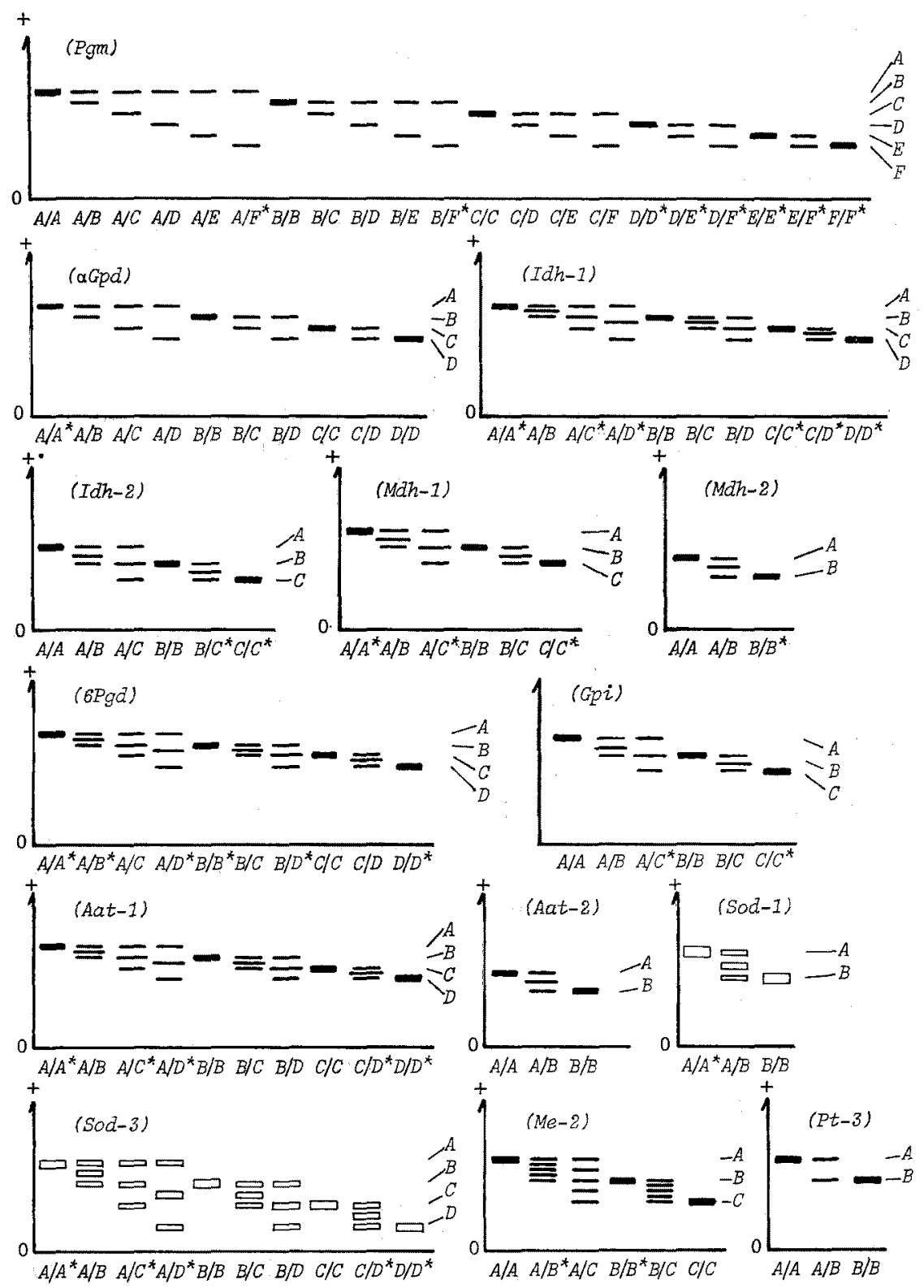

Fig. 2. Electrophoretic patterns of 14 enzyme loci in the scallop. Italic letters under the line of origin represent postulated genotype and those on the right-hand side show alleles. The genotypes marked "*" were not observed.

10 localities of native and sown scallops were scored for 19 loci. Of the 19 loci examined, five loci (Acp-1, Acp-2, Sod-2, Pt-1 and Pt-2) were observed to lack any variation in all localities. Nine loci were polymorphic and five showed a few variants in at least one locality (Table 1). A locus was considered polymorphic if the frequency of the most common allele was no greater than 0.95. Electrophoretic variations observed in the 14 loci and the postulated genotype for the respective variations are illustrated in Fig. 2.

The PGM and $\alpha$ GPD detected in adductor muscle showed the typical pattern of a monomer. These enzymes were coded by one gene locus being designated as $\mathrm{Pgm}$ and $\alpha \mathrm{Gpd}$, respectively. The different phenotypes indicated the presence of 6 alleles at the Pgm and 4 alleles at the $\alpha G p d$ locus.

The IDH activity appeared in two zones which were apparently coded by two gene loci (Idh-I 
and Idh-2). The Idh-1 locus exhibited a few variants in 7 localities and was monomorphic in 3 localities. The $I d h-2$ was polymorphic in 7 localities and a few variants were recognized in 3 localities. The adductor muscle showed the activity coded by $I d h-1$ locus and the digestive diverticula the activity coded by Idh-2 locus. The different phenotypes revealed the typical dimer, indicating 4 alleles at the $I d h-1$ and 3 alleles at the $I d h-2$ locus.

The MDH activity in adductor muscle appeared in two zones denoting two loci ( $M d h-1$ and $M d h-2)$. The $M d h-1$ locus exhibited a few variants in 8 localities and the $M d h-2$ locus in only a locality. The different phenotypes displayed the typical dimer, and represented 3 alleles at the $M d h-1$ and the 2 alleles at the $M d h-2$ locus.

6PGD detected in adductor muscle was the typical dimer, being coded by one locus $(6 \mathrm{Pgd})$. The different phenotypes indicated a few variants in 7 localities and the presence of 4 alleles.

The GPI examined in adductor muscle demonstrated the typical dimer, being coded by one gene locus (Gpi). The different phenotypes at this locus indicated polymorphism in all localities and the presence of 3 alleles.

The AAT activity in adductor muscle occurred in two zones, expressing the presence of two gene loci (Aat-1 and Aat-2). The Aat-1 and $A a t-2$ loci were polymorphic in all localities. The different phenotypes were indicative of the typical dimer, revealing 4 alleles at the Aat -1 and 2 alleles at the Aat-2 locus.

In adductor muscle, the SOD activity was detectable in three zones which were controlled by three loci (Sod-1, Sod-2 and Sod-3). The Sod-1 locus had a few variants in only a locality and Sod-2 locus was monomorphic, but Sod-3 locus was polymorphic in 2 localities and gave a few variants in 8 localities. The different phenotypes were indications of the typical dimer, manifesting the presence of 2 alleles at the Sod-I and four alleles at the Sod-3 locus.

The ME activity in adductor muscle was found in two zones implying two loci ( $M e-1$ and $M e-2)$. The $M e-1$ locus exhibited the activity also in digestive diverticula but has not yet been clearly scored in both two tissues. The $M e-2$ locus displayed polymorphism in 8 localities and a few variants in 2 localities.

PT appeared as many bands in adductor muscle extracts which were stained with amido black. Many bands were divided into five zones indicating five loci $(P t-1, P t-2, P t-3 . P t-4$ and $P t-5)$. The $P t-I$ and $P_{t-2}$ loci were monomorphic and the $P t-3$ locus was polymorphic in all localities. The different phenotypes at the $P t-3$ indicated the presence of 2 alleles. The number of bands at $P t-4$ and $P_{t-5}$ loci varied with the individuals, but the degree of staining of their bands was not so stable that these two loci were omitted from scoring.

The phenotypic distribution observed at each polymorphic locus in most of the localities was found to be in fair agreement with that expected from Hardy-Weinberg equilibrium, except for both the Aat-2 locus in sown Abashiri B and the $P t-3$ locus in Abashiri A and Abashiri C. The proportion of polymorphic loci was in the range of 0.368 to 0.421 , the average being 0.405 . The average heterozygosity calculated from the estimated gene frequencies was in the range of 0.147 to 0.169 , the average being 0.158 . The number of alleles per locus ranged from 1.7 to 2.2 , the average being 2.1 (Table 2).

\section{Genetic Difference among Populations}

A geographical cline of gene frequencies was not clearly recognized at all loci (Table 3 ). The test of significant heterogeneities for the frequency distribution of alleles revealed significant differences between all pairs of two localities, except a few combinations (Table 4). This indicated that any two of the 10 localities showed clear differences in gene frequencies and they were independent of each other, suggesting that each locality would have its own breeding population. However, there was no genetic difference between Abashiri A and Abashiri B in native populations.

Measures of genetic distance ${ }^{8)}$ were computed for all pairs of the 10 populations (Table 5). The mean genetic distance among the 10 populations was $0.0035 \pm 0.0003$. The mean genetic distance was $0.0041 \pm 0.0008$ among the native populations, and $0.0020 \pm 0.0005$ among the sown populations. The value suggests that the genetic differentiation is larger in native populations than in sown populations. The mean genetic distance between native and sown populations was $0.0034 \pm 0.0004$. The mean genetic distance between native Notoro Lake population and the other native populations was $0.0077 \pm 0.0008$.

To summarize the relations among populations, a dendrogram was drawn on the basis of similarity illustrated with an average of genetic distance (Fig. 3). The mean genetic distance was at its 
Table 2. Genetic variability in scallop population

\begin{tabular}{llccccc}
\hline & Locality & $\begin{array}{c}\text { Number of } \\
\text { individuals } \\
\text { tested }\end{array}$ & Age & $\begin{array}{c}\text { Proportion of } \\
\text { polymorphic } \\
\text { loci }\end{array}$ & $\begin{array}{c}\text { Average } \\
\text { heterozygosity }\end{array}$ & $\begin{array}{c}\text { Mean } \\
\text { number } \\
\text { of alleles }\end{array}$ \\
\hline \multirow{5}{*}{$\begin{array}{l}\text { Native } \\
\text { population }\end{array}$} & Notsuke & 30 & 7 or 8 yrs. & 0.421 & 0.147 & 1.7 \\
& Abashiri A & 50 & 28 mos. & 0.421 & 0.163 & 2.1 \\
& Abashiri B & 90 & $6-8$ yrs. & 0.421 & 0.160 & 2.2 \\
& Notoro Lake & 50 & 9 or 10 yrs. & 0.421 & 0.169 & 2.1 \\
& Saroma Lake & 100 & 40 mos. & 0.368 & 0.161 & 2.1 \\
Sown & Sarufutsu & 50 & 6 yrs. & 0.368 & 0.162 & 2.1 \\
population & Abashiri B & 100 & 35 or 41 mos. & 0.421 & 0.163 & 2.1 \\
& Abashiri C & 100 & 47 mos. & 0.421 & 0.149 & 2.0 \\
& Abashiri D & 100 & 23 mos. & 0.368 & 0.156 & 2.1 \\
& Yubetsu & 50 & 63 mos. & 0.421 & 0.150 & 2.0 \\
\hline
\end{tabular}

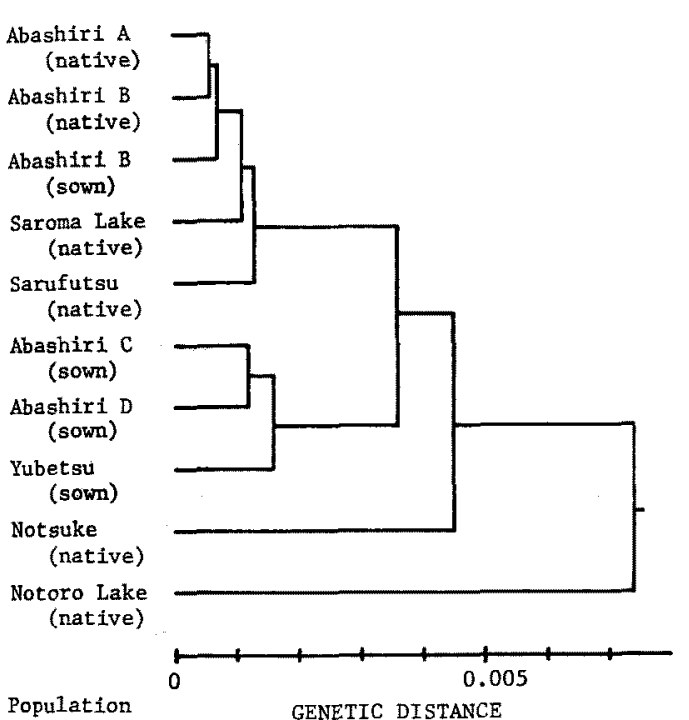

Fig. 3. Dendrogram drawn from genetic distance among populations of the scallop.

minimum between native Abashiri $\mathrm{A}$ and native Abashiri B population, and reached a maximum between native Notoro Lake population and the other populations.

\section{Discussion}

The estimate obtained in this work for the proportion of polymorphic loci and the average heterozygosity (Table 2) agrees with that from the scallop populations in the north-east Honshu. ${ }^{4)}$ Further, based on our work, scallops on the average are more heterozygous than fishes in general (proportion of polymorphic loci $=0.194 \pm$ 0.023 , average heterozygosity $=0.059 \pm 0.007){ }^{8)}$ SELANDER and KAUFMAN ${ }^{10}$ ) have pointed out that most of the invertebrates have high levels of genetic variability than most of the vertebrates, the interpretation being that the smaller and less mobile organisms experience their environments as more coarse-grained than the large and mobile forms.

As a whole, the present study has revealed that there are definite genetic differences among the scallop collections surveyed. This means that the breeding structure among the localities can be regarded as practically independent of each other. Furthermore, we note that the mean genetic distance as a whole (Table 5) is smaller than the value of 0.01 that is considered as the level of local race. ${ }^{8)}$ However, the result of the dendrogram (Fig. 3) indicates that the native Notoro Lake population significantly differs from the other populations in having the large genetic distance. This suggests that the scallops collected from Notoro Lake for the present work were not those which had been transplanted from other populations. The suggestion seems to be supported by the fact that this lake had been nearly isolated from the adjoining Okhotsk Sea until a permanent waterway to the open sea was constructed in 1974 .

The result that there is no difference in gene frequency between Abashiri A and Abashiri B in native populations suggests that the collection from Abashiri A, namely, 2-year-old natural scallops (Table 2) is the offsprings from the Abashiri B population. It is well known that, in the Abashiri A area, the seed scallops (collected in Notoro Lake and Saroma Lake) sown in 1978 suffered from mass mortalities involving more than $96 \%$ (as of September 1980) of the population. Since then, no sowing of seed scallops has been carried out and there have been no re- 
Table 3. Gene frequency at 14 enzyme loci in scallop population

\begin{tabular}{|c|c|c|c|c|c|c|c|c|c|c|c|}
\hline \multirow[b]{2}{*}{ Locus } & \multirow[b]{2}{*}{ Allele } & \multicolumn{6}{|c|}{ Native population } & \multicolumn{4}{|c|}{ Sown population } \\
\hline & & $\begin{array}{c}\text { Notsuke } \\
\text { (30) }\end{array}$ & $\begin{array}{c}\text { Abashiri } \\
\text { A } \\
(50)\end{array}$ & $\begin{array}{c}\text { Abashiri } \\
\text { B } \\
(90)\end{array}$ & $\begin{array}{c}\text { Notoro } \\
\text { Lake } \\
\text { (50) }\end{array}$ & $\begin{array}{c}\text { Saroma } \\
\text { Lake } \\
(100)\end{array}$ & $\begin{array}{c}\text { Sarufutsu } \\
\text { (50) }\end{array}$ & $\begin{array}{c}\text { Abashiri } \\
\text { B } \\
(100)\end{array}$ & $\begin{array}{c}\text { Abashiri } \\
C \\
(100)\end{array}$ & $\begin{array}{c}\text { Abashiri } \\
\text { D } \\
(100)\end{array}$ & $\begin{array}{c}\text { Yubetsu } \\
(50)\end{array}$ \\
\hline \multirow[t]{6}{*}{$P g m$} & $A$ & 0.167 & 0.100 & 0.133 & 0.120 & 0.105 & 0.110 & 0.075 & 0.070 & 0.070 & 0.080 \\
\hline & $B$ & 0.183 & 0.300 & 0.267 & 0.200 & 0.305 & 0.270 & 0.330 & 0.260 & 0.295 & 0.190 \\
\hline & $C$ & 0.650 & 0.560 & 0.550 & 0.550 & 0.515 & 0.580 & 0.535 & 0.635 & 0.575 & 0.680 \\
\hline & $D$ & 0 & 0.010 & 0.011 & 0.010 & 0.020 & 0 & 0.020 & 0.015 & 0.005 & 0.020 \\
\hline & $E$ & 0 & 0.030 & 0.033 & 0.120 & 0.055 & 0.040 & 0.040 & 0.020 & 0.055 & 0.030 \\
\hline & $F$ & 0 & 0 & 0.006 & 0 & 0 & 0 & 0 & 0 & 0 & 0 \\
\hline \multirow[t]{4}{*}{ Gpd } & $A$ & 0.017 & 0.030 & 0.017 & 0.030 & 0.025 & 0.020 & 0.025 & 0.015 & 0.010 & 0.020 \\
\hline & $B$ & 0.417 & 0.440 & 0.461 & 0.610 & 0.465 & 0.400 & 0.460 & 0.580 & 0.525 & 0.650 \\
\hline & $C$ & 0.516 & 0.480 & 0.417 & 0.310 & 0.465 & 0.450 & 0.445 & 0.325 & 0.365 & 0.240 \\
\hline & $D$ & 0.050 & 0.050 & 0.105 & 0.050 & 0.045 & 0.130 & 0.070 & 0.080 & 0.100 & 0.090 \\
\hline \multirow[t]{4}{*}{ Idh-I } & $A$ & 0 & 0 & 0 & 0.010 & 0 & 0 & 0 & 0.005 & 0 & 0 \\
\hline & $B$ & 0.983 & 0.980 & 1.000 & 0.970 & 0.995 & 1.000 & 0.990 & 0.985 & 1.000 & 0.990 \\
\hline & $C$ & 0.017 & 0.010 & 0 & 0.020 & 0.005 & 0 & 0.005 & 0.005 & 0 & 0.010 \\
\hline & $D$ & 0 & 0.010 & 0 & 0 & 0 & 0 & 0.005 & 0.005 & 0 & 0 \\
\hline \multirow[t]{3}{*}{$I d h-2$} & $A$ & 0.967 & 0.900 & 0.895 & 0.960 & 0.955 & 0.940 & 0.905 & 0.935 & 0.930 & 0.940 \\
\hline & $B$ & 0.033 & 0.100 & 0.094 & 0.040 & 0.045 & 0.060 & 0.095 & 0.065 & 0.070 & 0.060 \\
\hline & $C$ & 0 & 0 & 0.011 & 0 & 0 & 0 & 0 & 0 & 0 & 0 \\
\hline \multirow[t]{3}{*}{$M d h=1$} & $A$ & 0 & 0 & 0.006 & 0 & 0.010 & 0 & 0.005 & 0 & 0.005 & 0.010 \\
\hline & $B$ & 1.000 & 0.980 & 0.994 & 0.990 & 0.985 & 0.990 & 0.985 & 1.000 & 0.980 & 0.990 \\
\hline & $C$ & 0 & 0.020 & 0 & 0.010 & 0.005 & 0.010 & 0.010 & 0 & 0.015 & 0 \\
\hline \multirow[t]{2}{*}{$M d h-2$} & $A$ & 1.000 & 0.990 & 1.000 & 1.000 & 1.000 & 1.000 & 1.000 & 1.000 & 1.000 & $1 . .000$ \\
\hline & $B$ & 0 & 0.010 & 0 & 0 & 0 & 0 & 0 & 0 & 0 & 0 \\
\hline \multirow[t]{4}{*}{$6 P g d$} & $A$ & 0 & 0 & 0 & 0 & 0 & 0 & 0.005 & 0 & 0.010 & 0 \\
\hline & $B$ & 0 & 0.010 & 0.011 & 0 & 0 & 0.010 & 0 & 0.005 & 0 & 0 \\
\hline & $C$ & 1.000 & 0.960 & 0.972 & 1.000 & 1.000 & 0.990 & 0.985 & 0.990 & 0.990 & 0.990 \\
\hline & $D$ & 0 & 0.030 & 0.017 & 0 & 0 & 0 & 0.010 & 0.005 & 0 & 0.010 \\
\hline \multirow[t]{3}{*}{$G p i$} & $A$ & 0.083 & 0.060 & 0.106 & 0.110 & 0.105 & 0.110 & 0.075 & 0.065 & 0.120 & 0.130 \\
\hline & $B$ & 0.917 & 0.940 & 0.894 & 0.890 & 0.890 & 0.880 & 0.925 & 0.935 & 0.875 & 0.870 \\
\hline & $C$ & 0 & 0 & 0 & 0 & 0.005 & 0.010 & 0 & 0 & 0.005 & 0 \\
\hline
\end{tabular}




\begin{tabular}{|c|c|c|c|c|c|c|c|c|c|c|c|}
\hline \multirow[t]{4}{*}{ Aat-1 } & $A$ & 0 & 0 & 0.005 & 0 & 0.050 & 0.010 & 0 & 0 & 0 & 0 \\
\hline & $B$ & 0.850 & 0.820 & 0.829 & 0.630 & 0.770 & 0.700 & 0.785 & 0.815 & 0.840 & 0.800 \\
\hline & $C$ & 0.150 & 0.180 & 0.161 & 0.360 & 0.180 & 0.280 & 0.215 & 0.185 & 0.155 & 0.150 \\
\hline & $D$ & 0 & 0 & 0.005 & 0.010 & 0 & 0.010 & 0 & 0 & 0.005 & 0.050 \\
\hline \multirow[t]{2}{*}{ Aat -2} & $A$ & 0.367 & 0.470 & 0.467 & 0.580 & 0.445 & 0.470 & 0.505 & 0.525 & 0.495 & 0.510 \\
\hline & $B$ & 0.633 & 0.530 & 0.533 & 0.420 & 0.555 & 0.530 & 0.495 & 0.475 & 0.505 & 0.490 \\
\hline \multirow[t]{2}{*}{ Sod-1 } & $A$ & 0 & 0 & 0.006 & 0 & 0 & 0 & 0 & 0 & 0 & 0 \\
\hline & $B$ & 1.000 & 1.000 & 0.994 & 1.000 & 1.000 & 1.000 & 1.000 & 1.000 & 1.000 & 1.000 \\
\hline \multirow[t]{4}{*}{ Sod-3 } & $A$ & 0 & 0 & 0 & 0.050 & 0 & 0.010 & 0 & 0 & 0 & 0 \\
\hline & $B$ & 0.917 & 0.960 & 0.961 & 0.930 & 0.965 & 0.970 & 0.965 & 0.975 & 0.975 & 0.990 \\
\hline & $C$ & 0.083 & 0.040 & 0.033 & 0.020 & 0.035 & 0.020 & 0.035 & 0.025 & 0.025 & 0.010 \\
\hline & $D$ & 0 & 0 & 0.006 & 0 & 0 & 0 & 0 & 0 & 0 & 0 \\
\hline \multirow[t]{3}{*}{$M e^{-1}$} & $A$ & 0 & 0.040 & 0.050 & 0.030 & 0.040 & 0.020 & 0.085 & 0.090 & 0.040 & 0.020 \\
\hline & $B$ & 0.050 & 0.050 & 0 & 0.030 & 0.030 & 0.020 & 0 & 0 & 0.005 & 0.030 \\
\hline & $C$ & 0.950 & 0.910 & 0.950 & 0.940 & 0.930 & 0.960 & 0.915 & 0.910 & 0.955 & 0.950 \\
\hline \multirow[t]{2}{*}{$P t-3$} & $A$ & 0.467 & 0.310 & 0.289 & 0.520 & 0.400 & 0.350 & 0.355 & 0.370 & 0.455 & 0.420 \\
\hline & $B$ & 0.533 & 0.690 & 0.711 & 0.480 & 0.600 & 0.650 & 0.645 & 0.630 & 0.545 & 0.580 \\
\hline
\end{tabular}

Number in parenthesis represents number of individuals tested.

Table 4. A matrix of number of loci showing significant difference between every pair of populations in the scallop

\begin{tabular}{|c|c|c|c|c|c|c|c|c|c|c|c|}
\hline \multirow{2}{*}{\multicolumn{2}{|c|}{ Locality (Abbreviation) }} & \multicolumn{6}{|c|}{ Native population } & \multicolumn{4}{|c|}{ Sown population } \\
\hline & & Nk & An & $\mathrm{Bn}$ & No & $\mathrm{Sm}$ & $\mathrm{Sf}$ & Bs & $\mathrm{Cs}$ & Ds & Ys \\
\hline \multirow{6}{*}{$\begin{array}{l}\text { Native } \\
\text { population }\end{array}$} & Notsuke (Nk) & & & & & & & & & & \\
\hline & Abashiri A (An) & 0 & & & & & & & & & \\
\hline & Abashiri B (Bn) & 2 & 0 & & & & & & & & \\
\hline & Notoro Lake (No) & 3 & 4 & 5 & & & & & & & \\
\hline & Saroma Lake (Sm) & 1 & 1 & 4 & 5 & & & & & & \\
\hline & Sarufutsu (Sf) & 1 & 2 & 1 & 3 & 2 & & & & & \\
\hline \multirow{4}{*}{$\begin{array}{l}\text { Sown } \\
\text { population }\end{array}$} & Abashiri B (Bs) & 3 & 0 & 0 & 4 & 1 & 0 & & & & \\
\hline & Abashiri C (Cs) & 3 & 1 & 2 & 3 & 4 & 3 & 2 & & & \\
\hline & Abashiri D (Ds) & 1 & 2 & 2 & 1 & 2 & 2 & 0 & 2 & & \\
\hline & Yubetsu $\left(\mathrm{Ys}_{\mathrm{s}}\right)$ & 1 & 1 & 3. & 3 & 3 & 2 & 2 & 1 & 3 & \\
\hline
\end{tabular}




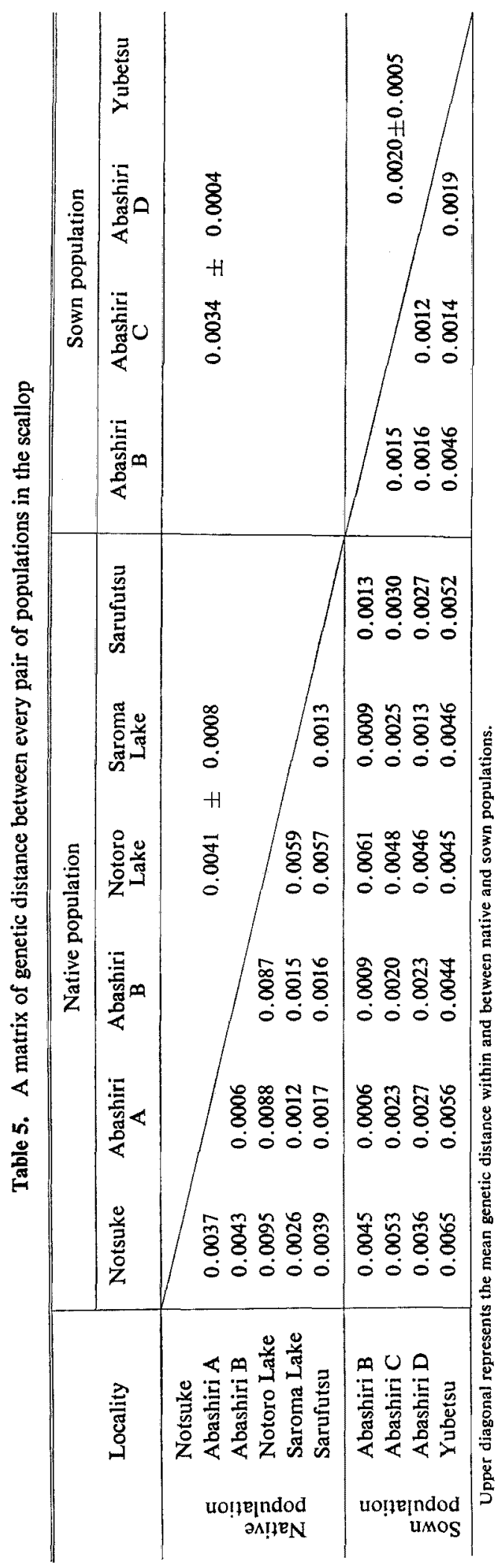

ports or information on the appreciable survival of natural or sown scallops in this area. In 1982, however, a fair number of 2-year-old natural scallops were found extensively there. These facts seem to support in part the above suggestion.

The fact that the genetic distance among sown populations is smaller than that among native populations (Table 5) suggests that the gene flow occurs more frequently among the sown populations. In order to elucidate the interaction between native and sown populations, the application of our results would afford one of the useful means, but additional other populations need to be screened.

In any event, it is certain that the scallop population has a structure capable of being split into a number of local subpopulations. This conclusion is consistent with the observation of Fujio ${ }^{2}$ ? regarding the population structure of wild Japanese oysters Crassostrea gigas.

\section{Acknowledgements}

We wish to express our sincere thanks to Professors Kazuhiko KonisHI (Faculty of Science) and Tadashi Nomura (Faculty of Agriculture) of Tohoku University for making it possible to carry out this study and for their interest and encouragement. Particular thanks are due to the staff of the Abashiri Scallop Research Laboratory, Abashiri, Hokkaido, who cooperated with us in collecting and pretreating the experimental materials. This study was supported in part by the Grant-in-Aid for Scientific Research (No. 57560177) from the Japanese Ministry of Education, Science and Culture to K. MoRI.

\section{References}

1) A. G. Johnson and F. M. UTTER: Anim. Blood Grps biochem. Genet., 6, 71-80 (1975).

2) Y. Fusı: Tohoku J. Agr. Res., 30, 32-42 (1979).

3) K. Fumno and M. Matsuya: Fish Genet. Breed. Sci., 5, 13-17 (1980).

4) R. YAMANAKA and Y. Fujio: Fish Genet. Breed. Sci, 8, 33-37 (1983a).

5) R. Yamanaka and Y. Fujo: Fish Genet. Breed. Sci., 8, 38-41 (1983b).

6) C. R. Shaw and R. Prasad: Biochem. Genet., 4, 297-320 (1970).

7) M. Sugita and Y. Fujo: Tohoku J. Agr. Res., 33, 42-49 (1982).

8) M. NeI: Amer. Natur., 106, 283-292 (1972).

9) Y. Furno and Y. KaTo: Bull. Japan. Soc. Sci. Fish., 45, 1169-1178 (1979).

10) R. K. Selander and D. W. Kaufman: Proc. Natl. Acad. Sci. U.S.A., 70, 1875-1877 (1973). 